be asked, is any of these variates an actual signal, or may each not be a reflection of other real signals or even of a common signal?

Any single control hypothesis would have to propose a feature common to each of the proximate principles, and would also have to satisfy the requirements of shortterm and long-term control. It seems likely that the conflict between short-term and long-term control could be resolved by the differences in threshold of the two centres, without distinct mechanisms being invoked. A common signal, however, is more easily proposed than found. At no point are the metabolic paths of protein, fat and carbohydrate coincident although they do overlap to some extent. At this stage it is convenient to accept Brobeck's (1957) suggestion of a 'multiple factor' control, by analogy with the control of respiration, as a working basis for further investigation. It would be helpful, however, if the number of mechanisms involved and receptors to be found could be reduced. Multiple-factor theories, which are entirely empirical, are always unsatisfactory.

\title{
REFERENCES
}

Adolph, E. F. (1947). Amer. F. Physiol. r5r, i 10.

Anand, B. K. \& Brobeck, J. R. (1951). Yale ¥. Biol. Med. 24, I23.

Brobeck, J. R. (1948). Yale F. Biol. Med. 20, 545.

Brobeck, J. R. (1957). Yale F. Biol. Med. 29, 565 .

Brobeck, J. R., Tepperman, J. \& Long, C. N. H. (1943). Yale F. Biol. Med. 15, 33 I.

Cannon, W. B. \& Washburn, A. L. (Igra). Amer. F. Physiol. 29, 441.

Erdheim, J. (1904). S.B. Akad. Wiss. Wien, Abt. iii, I13, 537.

Gasnier, A. \& Mayer, A. (1939). Ann. Physiol. Physicochim. biol. 15, 57.

Hervey, G. R. (1959). F. Physiol. 145, 336.

Hetherington, A. W. \& Ranson, S. W. (1939). Proc. Soc. exp. Biol., N.Y., 41, 465.

Janowitz, H. D. \& Hollander, F. (1955). Ann. N.Y. Acad. Sci. 63, 56.

Kennedy, G. C. (1953). Proc, roy. Soc, B, 140, 578.

Larsson, S. (1954). Acta physiol. scand. 32, suppl. 115.

Mayer, J. (1953). Physiol. Rev. 33, 472.

Mayer, J. (1955). Nutr. Abstr. Rev. 25, 597.

Mayer, J. \& Morrison, S. D. (1958). F. Physiol. r43, 4I $P$.

Miller, N. E. (1955). Ann. N.Y. Acad. Sci. 63, I4I.

Morrison, S. D., Lin, H. J., Eckel, H. E., Van Itallie, T. B. \& Mayer, J. (1958). Amer. F. Physiol. 193, 4. Morrison, S. D. \& Mayer, J. (1957). Amer. F. Physiol. I91, 248.

Teitelbaum, P. \& Campbell, B. A. (1958). F. comp. physiol. Psychol. 51, 135.

\section{The measurement of body fat in man}

By J. M. Tanner, Institute of Child Health, University of London, Hospital for Sick Children, Great Ormond Street, London, W.C.I

\section{Introduction}

The methods available for estimating body fat in man are ( $\mathrm{r}$ ) anthropometric, by measurement of the thickness of subcutaneous tissue by calipers or by radiography; (2) direct physical and chemical (not applicable to living persons), by fat-solvent extraction of the whole body or parts of it; (3) indirect physical and chemical, by measurement of body density or body water, or a combination of the two, various assumptions being made; (4) indirect anthropometric. 
The chief difference between anthropometric and physico-chemical methods is that the former give information about the relative distribution of fat from region to region, as well as indirectly about the total amount of body fat, whereas the latter give information only about the total amount of fat. Thus the most searching studies of body fat necessarily include both anthropometric and physico-chemical measurements.

\section{Anthropometric methods}

\section{Skinfolds}

Measuring instrument. The observer pinches up a layer of skin and subcutaneous fat between his finger and thumb and applies some form of caliper to the fold to measure its thickness. References to the early literature will be found in the papers of Kornfeld \& Schüller (1930) and of Reynolds (1950). The usefulness of this technique has been limited in the past by lack of a suitable measuring instrument and lack of a clear definition of the sites of the body where the skinfolds can be picked up.

Only calipers designed to give a constant pressure at all separations of the jaws are acceptable and of these the Harpenden Skinfold Caliper (Tanner \& Whitehouse, $1955^{a}$ ) is the most accurate, most simply used and most readily available. There is international agreement that the pressure exerted on the skinfold at the caliper face should be $10 \mathrm{~g} / \mathrm{mm}^{2}$ and that it should be constant over a range of openings from 2 to at least $40 \mathrm{~mm}$. There is no agreement yet on the desirable area and shape of the jaw face, which is $90 \mathrm{~mm}^{2}$ and rectangular in the Harpenden caliper, and varies from 25 to $40 \mathrm{~mm}^{2}$, either round or rectangular, in various editions of the American Minnesota caliper. The Harpenden caliper has been extensively tested on behalf of the Medical Research Council, and its accuracy, both for a single observer and between different observers, has been rigorously assessed (Edwards, Hammond, Healy, Tanner \& Whitehouse, I955). There are at present some $25^{\circ}$ of these instruments in use throughout the world.

No skinfold caliper can give an accurate indication of the thickness of subcutaneous tissue unless the fold is picked up in a standard fashion. The thumb and forefinger of the left hand should be placed just sufficiently far apart so that a full fold is pinched up clean away from the underlying tissue. The fold should be pinched up firmly and held between the fingers all the time the measurement is being taken. The calipers are applied to the fold a little below the fingers so that the pressure on the fold at the point measured is exerted by the caliper faces and not by the fingers. The dial of the Harpenden caliper is then read to the nearest $0.1 \mathrm{~mm}$. Over most of the commonly met range of readings this technique results in a clear and stable reading. Above about 20 or $25 \mathrm{~mm}$, however, the value registered sometimes decreases as one watches the pointer on the dial. This decrease can usually be stopped by taking a rather firmer pinch with the left hand; on the rare occasions when it continues, the reading must be taken immediately after application of the spring's pressure. 
Sites of measurement. Skinfolds can be accurately measured only at sites where a proper fold can be raised. International standardization is here half-way to being reached. The two most commonly used folds are: (I) Triceps-half-way down the left arm between the tip of the acromion and the top of the radius, with the fold picked up in a line passing directly up the arm from the tip of the olecranon process. The arm hangs relaxed at the side. (2) Subscapular-just below the angle of the left scapula, the fold being picked up parallel to the natural cleavage line of the skin.

In addition to these two sites, sites over the biceps muscle, above the iliac crest, immediately under the costal margin and close by the umbilicus have been used and sites in the thigh and calf in subjects in whom a true fold can be picked up there. (See for example, Brožek \& Keys, 195I; Hammond, 1955; Pascale, Grossman, Sloane \& Frankel, 1956.) In the Canadian survey of 22000 people the triceps measurement was used as the best single measurement (Pett \& Ogilvie, 1956). It is also being used in the London County Council survey of schoolchildren, now in progress, together with the subscapular measurement. The Committee on Nutritional Anthropometry of the (U.S.) National Research Council recommended for general survey use the triceps and subscapular measurements (Anonymous, 1956). Some investigators use the right-hand side of the body, but since by international agreement all anthropometry has been carried out on the left side for the last 70 years there would seem no point in nutritionists departing from this custom.

Frequency distribution. The frequency distributions of the values obtained by the skinfold calipers are always markedly non-Gaussian with a long tail to the right. Furthermore, the error of measurement is proportional to the absolute measurement registered. It is therefore necessary for most purposes to transform these measurements, and when the Harpenden Skinfold Caliper is used a transformation appropriate to most or all sites, for both sexes and all ages, is:

Skinfold transform $=100$ (reading in $0.1 \mathrm{~mm}-18$ ).

A table of the transform is given by Edwards et al. (I955). Since a double thickness of skin under $10 \mathrm{~g} / \mathrm{mm}^{2}$ pressure averages just about $\mathrm{I} .8 \mathrm{~mm}$, it seems that the distribution of fat itself is almost exactly log-normal.

Accuracy of measurement. The accuracy of measurement of triceps and subscapular skinfolds taken with the Harpenden caliper is such that a trained individual should duplicate his readings to within $\pm 0.3 \mathrm{~mm}$ in two-thirds of all repeated measurements at the average opening of about $8 \mathrm{~mm}$. At greater openings the absolute accuracy is less, but the percentage duplication stays constant at about $5 \%$ for two-thirds of the readings. Differences between different observers may be twice this amount, however, unless great care is taken in training the observers together and in keeping them so trained.

\section{Radiographic thickness of subcutaneous tissue}

The shadow of skin plus subcutaneous tissue can be readily distinguished from that of the underlying muscle on a suitably exposed X-ray film. Given standardized conditions its width can be accurately estimated. Techniques have been described by Stuart, Hill \& Shaw (1940), Reynolds (1944), Garn (1954) and Tanner (1955). 
The last author gives a technique for estimating the thickness of fat in calf, thigh and upper arm. If this X-ray procedure is used the subject should be provided with the 'Armadillo' protective clothing to prevent radiation from reaching the gonads (Tanner, Whitehouse \& Powell, 1958). The width of the subcutaneous fat layer is measured to the nearest $0.1 \mathrm{~mm}$ with a caliper designed for the purpose (Tanner $\&$ Whitehouse, I955 ${ }^{b}$ ). Garn (1954) has presented a method for nine fat sites, including some in the thorax, and Baker, Hunt $\&$ Sen (1958) also present a technique applicable to the forearm.

The frequency distributions for these regions of fat are also non-Gaussian and the logarithms of the values obtained rather than the straight values should be used for most purposes.

The correlation between measurement of skinfold by caliper and of subcutaneouslayer thickness by radiography at the same site is about 0.85 (Garn \& Gorman, 1956; Brožek \& Mori, 1958; Hammond, r955; Baker et al. 1958).

\section{Sites of measurement}

It would be desirable to know which sites of measurement predict best the total body fat, but it is not certain at present. It is clear, however, that the correlations between skinfolds or radiographic layers taken at different parts of the body are always high, and therefore no very great difference in predictive value occurs, at least as between some half-dozen different measurements (see Garn, 1954, 1957a,b). The correlations between total body fat determined by densitometry and two or three skinfold measurements are of the order of 0.8 (Brožek \& Keys, I95I; Pascale et al. 1956; Allen, Peng, Chen, Huang, Chang \& Fang, 1956; Brožek \& Mori, 1958). It has not been sufficiently realized, however, that the densitometry method by itself is a very inefficient measure of body fat (see below) and hence this correlation should not be taken as an indicator of the goodness or otherwise of skinfold measurements, but rather viewed as the result obtained by applying two equally fallible methods.

\section{Norms for subcutaneous fat}

No very satisfactory norms exist at present for the now internationally accepted caliper pressure of $10 \mathrm{~g} / \mathrm{mm}^{2}$. Hammond (1955) gives means for six skinfolds at each year of age from 2 to 18 in both sexes, but without figures indicative of the spread of his distributions. Brožek (1956) gives the frequency distributions at two sites for $23^{8}$ middle-aged Americans. Pett \& Ogilvie (1956) give Ioth, 25th, 5oth, 75th and 90 th percentiles for triceps skinfolds for both sexes from age 2 each year to age 20 and then in 5 -year groups to $65+$. These values are based on measurements on 22000 Canadians selected from the whole population by proper census-type sampling methods. Though they agree well with Hammond's English measurements they are considerably below Brožek's American figures and other figures for American servicemen. Norms for the radiographic fat-layer measurements have been given by Garn (1954, 1957c) together with some indications of age changes from 20 to 60 years (Garn \& Saalberg, 1953; Garn \& Harper, I955; Garn \& Young, 1956). Norms for 
radiographic measurements in children will be found in papers cited by Tanner (I955, p. I7).

\section{Body-weight as a measure of body fat}

Body-weight, even when corrected by the appropriate regression equation for stature above or below the average, is a most imperfect guide to body fat. Welham \& Behnke (1942) showed that professional football players averaged some $25 \%$ overweight by American Army acceptance standards. It is clear that to get an estimate of fat in a given person one needs to measure the amount of fat and not infer it from body-weight. However, when one wishes to study changes of body fat in a given individual over a period of time, body-weight changes do reflect changes in fatty tissue, unless athletic training is being undertaken and except for the water gain or loss which may occur in the first few days of changed conditions.

\section{Physical and chemical methods}

No direct chemical method of measuring body fat in the living person is yet available. Indirect methods rely on estimating either body density or body water or preferably both. The basic principles of these methods, together with their assumptions and accuracy, have been excellently discussed by Siri (I956a). Earlier reviews are those of Keys \& Brožek (1953) and Brožek \& Keys (I950-I).

Principle. The constituents of the body are regarded solely as lipids, water, proteins and minerals. The weight of any person is then expressed as the weight of his fat $(f)$, water $(w)$, protein $(p)$ and minerals $(m)$, each expressed as a proportion or percentage of body-weight, thus:

$$
\mathbf{I}=\mathrm{f}+\mathrm{w}+\mathrm{p}+\mathrm{m} .
$$

Since volume $=$ weight $\div$ density $(d)$, we also have the equation

$$
\frac{\mathrm{I}}{\mathrm{d}}=\frac{\mathrm{f}}{\mathrm{d}_{\mathrm{f}}}+\frac{\mathrm{w}}{\mathrm{d}_{\mathrm{w}}}+\frac{\mathrm{p}}{\mathrm{d}_{\mathrm{p}}}+\frac{\mathrm{m}}{\mathrm{d}_{\mathrm{m}}}
$$

Our first set of assumptions is that the densities of fat, water, protein and mineral are the same in all people and that at $37^{\circ}$ they have the following values:

$$
\mathrm{d}_{\mathrm{f}}=0.900 \mathrm{~g} / \mathrm{cm}^{3} ; \mathrm{d}_{\mathrm{w}}=0.993 \mathrm{~g} / \mathrm{cm}^{3} ; \mathrm{d}_{\mathrm{p}}=\mathrm{I} \cdot 340 \mathrm{~g} / \mathrm{cm}^{3} ; \mathrm{d}_{\mathrm{m}}=3.000 \mathrm{~g} / \mathrm{cm}^{3} \text {. }
$$

Justification for these assumptions is most difficult for fat, but is provided by the work of Fidanza, Keys \& Anderson (1953).

We have now two equations for four unknowns. It is therefore necessary to assume certain relationships equivalent to introducing two further equations. In the densityalone or body-water-alone methods one of two assumptions is made: either (a) that the body consists of a fat-free portion which has precisely the same composition in all persons and to which is added fat in varying amounts, or (b) that the given person investigated differs from a 'standard reference man' only in having a different proportion of adipose tissue, this adipose tissue being assumed to have a known composition which is constant for all persons at all levels of body fat. Brožek's (I952) standard 
reference man has the following proportional composition in terms of body-weight:

$$
\mathrm{f}_{R}=0.14 ; \mathrm{w}_{R}=0.61 ; \mathrm{p}_{\mathrm{R}}=0.19 ; \mathrm{m}_{\mathrm{R}}=0.06 \text {. }
$$

A proportional composition of adipose tissue may be represented by Keys \& Brožek's (1953) figures:

$$
\mathrm{f}_{\mathrm{A}}=0.62 ; \mathrm{w}_{\mathrm{A}}=0.3 \mathrm{r} ; \mathrm{p}_{\mathrm{A}}=0.07 ; \mathrm{m}_{\mathrm{A}}=0.00 \text {. }
$$

In fact, the exact composition of adipose tissue is at present disputed (Passmore, Meiklejohn, Dewar \& Thow, 1955; Passmore, Strong \& Ritchie, 1958). With the values for Brožek's standard reference man we get for the density equation:

$$
\mathrm{f}=\frac{4 \cdot 20 \mathrm{I}}{\mathrm{d}}-3.8 \mathrm{r} 3 \text {. }
$$

With the fat-free body as reference we have:

$$
f=\frac{4 \cdot 95^{\circ}}{d}-4 \cdot 500 \text {. }
$$

For the body-water method, with the same assumptions, the equations are: based on Brožek's standard reference man

based on the fat-free body

$$
f=r \cdot 016-r \cdot 600 w,
$$

$$
f=I \cdot 000-I \cdot 390 w
$$

It will readily be seen that the assumptions made for the density-alone and wateralone methods are far from being met in practice and for this reason the error introduced solely by these assumptions, and not by any experimental inaccuracy, is about $\pm 3.8 \%$ of body-weight. This is the absolute limit of accuracy of either the density-alone or body-water-alone methods. As the average man has about $14 \%$ body fat the error is approximately $\pm 27 \%$ of the average value of the variable we are trying to estimate. Thus only in two-thirds of our observations will we be within even these limits of the true figure for body fat.

Combined density and body-water method. Combined measurements of density and body water give a method that does away with the necessity for a reference man and for the assumption of constancy of composition of adipose tissue. It is applicable in abnormal states of hydration and in the presence of ascites or other fluid accumulations. It involves a biological assumption error of only about half that of the density-alone or body-water-alone methods and is therefore the method of choice at present. It depends on a combined formulation using equations ( $\mathrm{I}$ ) or (2) together with the assumption, $m=\alpha p$, i.e. that the ratio of mineral to protein weight is the same in all individuals. The estimating equation is:

$$
\mathrm{f}=\frac{2 \cdot \mathrm{I} I 8}{\mathrm{~d}}-0 \cdot 780 \mathrm{~W}-\mathrm{I} \cdot 354
$$

on the assumption that $\alpha=0.35$. The total error involved in this combined method is approximately $\pm 2 \%$ body-weight, equivalent to $\pm 14 \%$ of the mean value of the variate estimated. This error is now made up of $6 \%$ due to measuring error of body density, $60 \%$ due to measuring error of body water and $34 \%$ due to biological assumption error. 
Methods for density and body-water. Body density can be measured either by (I) underwater weighing (Behnke, Feen \& Welham, 1942), the water being kept at $37^{\circ}$ and the residual air in the lungs measured, or (2) by the displacement of air by the body in an air-tight chamber of known volume (Siri, I956b). The second method is greatly preferable, particularly in clinical circumstances, but the apparatus is at present costly. The amount of air displaced is measured by the technique of helium dilution.

Body water may be measured by administration in drinking water of a small amount of tritium or deuterium oxide, or by giving antipyrine or possibly urea or other substances. With tritium the dose of radiation administered is exceedingly small and far within limits considered safe. Labelled hydrogen atoms however do undergo some exchange with hydrogen in the body proteins leading, it is believed, to an overestimation by $2 \%$. Antipyrine suffers from the reverse disadvantage in that it binds slightly to the plasma proteins and may be slightly metabolized, which leads to some underestimation.

Probably the most accurate determination of total body fat that can be obtained at present is through the 'combined' physico-chemical methods, though the error is still considerable. Because there is no way of validating any of the methods, we cannot tell whether the thickness of skinfolds estimates total fat more or less accurately than the physico-chemical methods. Present information suggests that the results of the two methods do in fact agree fairly closely.

\section{REFERENCES}

Allen, T. H., Peng, M. T., Chen, K. P., Huang, T. F., Chang, C. \& Fang, H. S. (1956). Metabolism, $5,346$.

Anonymous (1956). Hum. Biol. 28, 111 .

Baker, P. T., Hunt, E. E. \& Sen, T. (1958). Amer. F. phys. Anthrop. N.S. 16, 39.

Behnke, A. R. Jr., Feen, B. G. \& Welham, W. C. (I942). F. Amer. med. Ass. 118, 495.

Brožek, J. (1952). Fed. Proc. 11, 784 .

Brožek, J. (1956). Hum. Biol. 28, 124.

Brožek, J. \& Keys, A. (1950-1). Nutr. Abstr. Rev. 20, 247.

Brožek, J. \& Keys, A. (1951). Brit. F. Nutr. 5, 194.

Brožek, J. \& Mori, H. (1958). Hum. Biol. 30, 322.

Edwards, D. A. W., Hammond, W. H., Healy, M. J. R., Tanner, J. M. \& Whitehouse, R. H. (1955). Brit. F. Nutr. 9, 133 .

Fidanza, F., Keys, A. \& Anderson, J. T. (1953). F. appl. Physiol. 6, 252.

Garn, S. M. (1954). Hum. Biol. 26, 59.

Garn, S. M. (1957a). Science, 125, 550 .

Garn, S. M. (1957b). Hum. Biol. 29, 337.

Garn, S. M. (1957c). Science, 125, 1091.

Garn, S. M. \& Gorman, E. L. (I956). Hum. Biol. 28, 407.

Garn, S. M. \& Harper, R. V. (1955). Hum. Biol. $27,39$.

Garn, S. M. \& Saalberg, J. H. (I953). Hum. Biol. 25, 144.

Garn, S. M. \& Young, R. W. (1956). Amer. 7. phys. Anthrop. N.S. 14, 497.

Hammond, W. H. (1955). Brit. F. prev. soc. Med. 9, 201.

Keys, A. \& Brožek, J. (1953). Physiol. Rev. 33, 245.

Kornfield, W. \& Schüller, H. (I930). Z. Kinderheilk., 49, 277.

Pascale, L. R., Grossman, M. I., Sloane, H. S. \& Frankel, T. (1956). Hum. Biol. $28,{ }^{6} 5$.

Passmore, R., Meiklejohn, A. P., Dewar, A. D. \& Thow, R. K. (1955). Brit. F. Nutr. 9, 27.

Passmore, R., Strong, J. A. \& Ritchie, F. J. (1958). Brit. F. Nutr. I2, 13.

Pett, L. B. \& Ogilvie, G. F. (1956). Hum. Biol. 28, I77. 
Reynolds, E. L. (1944). Child Developm. 15, I 8 I.

Reynolds, E. L. (1950). Monogr. Soc. Res. Child Developm. 15, no. 2.

Siri, W. E. (1956a). Body Composition from Fluid Spaces and Density: Analysis of Methods. MS no. UCRL 3349: Donner Laboratory, University of California.

Siri, W. E. (1956b). Rev. sci. Instrum. 27, 729.

Stuart, H. C., Hill, P. \& Shaw, C. (1940). Monogr. Soc. Res. Child Developm. 5, no. 3.

Tanner, J. M. (1955). Growth at Adolescence. Oxford: Blackwell's Scientific Publications.

Tanner, J. M. \& Whitehouse, R. H. (1955a). Amer. F. phys. Anthrop. N.S. 13, 743.

Tanner, J. M. \& Whitehouse, R. H. (1955b). Nature, Lond., 176, 1 I 80.

Tanner, J. M., Whitehouse, R. H. \& Powell, J. H. (1958). Lancet, ii, 779.

Welham, W. C. \& Behnke, A. R. Jr. (1942). F. Amer. med. Ass. I18, 498.

\section{Some aspects of metabolism of the obese}

By G. L. S. Pawan, Department of Medicine, Middlesex Hospital, London, W.

For many generations obesity has been a subject of major interest in countries with a high standard of living and readily available food supplies, and in recent years a voluminous literature on this condition has accumulated in both the lay and medical press. Much work has been carried out on metabolism in the obese; there has been even more speculation, but the problem still remains a vexed one.

In this paper, only certain aspects of metabolism in the obese human being will be presented. The many important contributions of various workers have been reviewed by others (Rynearson \& Gastineau, 1949; Newburgh, 1950; Evans, 1952; McCance, I953a, $b$; Mayer, I953, I955a,b, 1957; Bernhardt, I955; Berryman, I955; Vague \& Benoit, I956).

More than 50 years ago, von Noorden (1907) suggested a classification of obesity into (a) an exogenous or simple type caused by manifest overeating, and (b) an endogenous type produced by, or associated with, various metabolic abnormalities. The work of Newburgh and his collaborators (Newburgh, 1950) appeared to refute the existence of this latter type, and as a result attention has largely been focused on the factors regulating appetite and food intake; the usual treatment has been to reduce total calorie intake, by devious means, below the theoretical calorie requirement of the individual.

In recent years, the experiments of Mayer and his colleagues (Mayer, I957) in particular have shown the definite existence of 'metabolic' abnormalities in certain types of obesity in animals: these are distinct from 'regulatory' types of obesity in which mainly factors controlling food intake are deranged. In man, despite the belief of Newburgh (1950) that metabolism in the obese subject differs in no respect from that in the non-obese, it is felt by some that the question is far from settled and that much is yet to be learned about obesity from careful metabolic studies on man.

In the mid-nineteenth century, William Banting (1864) observed on himself that weight was lost most readily on a diet low in carbohydrate. More recently, Pennington (195 I, I954) has attributed obesity in man to a defect in carbohydrate metabolism and has reported successful treatment of the condition with an unrestricted calorie intake from diets high in fat and low in carbohydrate. However, the 